\title{
Amending the Love Story
}

Studies of French translations of Jane Austen document an overwhelming tendency, particularly in the nineteenth century, to adapt Austen's stories to the model of popular romances and novels of sensibility. ${ }^{1}$ This sometimes meant modifying her characters, plots and language in order to achieve a more conventional, sentimental story. In the extreme cases, new characters are introduced, events are added and a more romantic vocabulary employed. As Isabelle Bour comments on observing the alterations and modifications in Isabelle de Montolieu's 1815 translation of Sense and Sensibility, "she must have felt ... that Austen was too unromantic". ${ }^{2}$

The Norwegian reception is never quite ready to alter Jane Austen's stories so blatantly. Still, the tendency is there, albeit in milder forms. It testifies to challenges of transmitting her authorship, not least the ironic or critical aspects of it. Compared to French sentimental translations, there is not in Norway a consistent omission of wit, reinterpreting of characters, amending of plotlines, or other such crude editing. Furthermore, the only Norwegian nineteenth-century translation, the 1871 Familien Elliot (Persuasion), is one of the two most conscientious translations of all periods, demonstrating a fundamental understanding of Austen's novel.

However, there are factors that draw Norwegian translations in the same direction as the French sentimental ones. Alf Harbitz' 1930 preface and book design, Lalli Knutsen's 1947 profession and genre, the romance market 1991 edition of the Hauges' c. 1972 translation, and Merete Alfsen's 2003 nostalgia, are all such elements, and more will be discussed below. ${ }^{3}$

The great paradox of Austen's popularity is that she is much praised for her enchanting love stories, and yet, she never refrains from reminding us that there is no such thing as perfect happiness. How are these reminders treated by translators? Why do two of the translations of Pride and Prejudice cut the sentence "there was still something to be wished for", in the midst of the happy

1 Such studies have been carried out in Isabelle Bour, "The Reception of Jane Austen's Novels in France and Switzerland", 2014; Valérie Cossy, Jane Austen in Switzerland, 2006; Lucille Trunel, "Jane Austen's French publications from 1815", 2013.

2 Bour, 22.

3 See pages $25^{-27}, 28,36,64,137$ and 185 above.

(C) MARIE NEDREGOTTEN SøRBø, 2018 | DOI 10.1163/9789004337176_014

This is an open access chapter distributed under the terms of the prevailing CC-BY-NC License. 9789004337176 
ending, after the proposal and after the parents' consent?' In a conventional romance, there is nothing more to be wished for. In Austen's story, there are still the parental shortcomings, the burden of having a stupid mother and other silly family members, which tend to poison the happiness. In fact, they "took from the season of courtship much of its pleasure" (384), a rather dampening statement that is left out of all except the most recent translation. ${ }^{5}$

\section{Avoiding Disillusioned Marriages}

Two of the Norwegian translators of Pride and Prejudice seem to shy away from Austen's starkly ironic dismissal of the main marriage of the novel, the Bennets, as it is revealed in the first pages of II, $19(236-37)$. They cut the first half (Harbitz) and more (the 1974 translation) of the chapter. They thereby discard the description of the unhappy marriage, Mr Bennet's disillusionment and his "breach of conjugal obligation" in ridiculing his wife. Although both these translators also take great liberties elsewhere in editing the text of the novel, this particular omission smacks of censorship. The passages are very readable and even funny and cannot have been omitted on this account.

A third translation (the Hauges') fortunately preserves most of these passages, but loses the narrator's exquisite comment on Mr Bennet taking comfort in laughing at his stupid wife:

This is not the sort of happiness which a man would in general wish to owe to his wife; but where other powers of entertainment are wanting, the true philosopher will derive benefit from such as are given. (236)

The comment is a typical example of Austen's mixture of ironic perspective and comic relief, and sorely missed when it is gone. Only two of the five translations preserve it. ${ }^{6}$

4 Austen, Elisabeth og hennes søstre, 1930, 246; Austen, Stolthet og fordom, 1947, 328.

5 "De ubehagelige fornemmelser som uvegerlig gjorde seg gjeldende av denne grunn, [deleted clause] ble lindret ved tanke på fremtiden" (Austen, Stolthet og fordom, c. 1972, 307). Alfsen has translated it accurately: "berøvet forlovelsestiden mye av dens glede" (Austen, Stolthet og fordom, 2003, 354).

6 The narrative comment is omitted in Austen, Stolthet og fordom, c. 1972, 191. It is only (and well) translated by Knutsen and Alfsen (Austen, Stolthet og fordom, 1947, 205-206; Austen, Stolthet og fordom, 2003, 223). 
Then, there is a second occasion where the Bennet marriage (which appears inauspicious throughout) is brought out in sharp relief. When Mr Bennet talks to Elizabeth about marrying Darcy, he clearly alludes to his own unhappy marriage, and begs his daughter not to make the same mistake:

My child, let me not have the grief of seeing you unable to respect your partner in life. You know not what you are about. (376)

In a chapter that is otherwise not much reduced, Harbitz omits some key words and makes Mr Bennet only say: "Dear child, let me not have this grief. You do not know what you are about to do". Again, this must be deliberate censorship on the part of the translator. ${ }^{7}$

The same omission is seen in the 1974 translation, while Knutsen keeps the first sentence, cuts the second, and effectively reduces Mr Bennet's allusion to himself by removing the italicization of you. The Hauges have kept both sentences, but again without the italics. Merete Alfsen is the only translator who renders Mr Bennet's meaning fully. ${ }^{8}$

This passage is one of the darkest expressions of married unhappiness ("you know not what you are about") from the mouth of a disillusioned man. Mr Bennet is not joking and he is not being facetious here - for once he is utterly serious. It is a deeply moral issue: a question of trading one's soul and integrity for money and security. At the same time, it is a striking feminist argument, and a double one. Not only is there a point that women should not sell their ideals for social status and a safe income. There is also the indisputable case that $\mathrm{Mr}$ Bennet sees his daughter as superior in intelligence and integrity to the richest man of their acquaintance. He really means that she would be unhappy to have a husband that cannot measure up to her own intellectual and moral standards. These explicit and implied ideas are presumably worth rendering in translation.

Persuasion is somewhat different when it comes to the depiction of marriage, insofar as the main parent is a widower. However, marriage, including its disillusioning aspects, remains a major issue. From the beginning, we get a vivid impression of the unequal marriage the Elliots must have had when Lady Elliot was still alive - in fact it is exactly the kind of marriage Mr Bennet is warning his daughter about ("a wife of very superior character to any thing

7 "Kjære barn, la mig ikke ha den sorg. Du vet ikke hvad du står i ferd med å gjøre" (Austen, Elisabeth og hennes søstre, 1930, 245).

8 Austen, Stolthet og fordom, 1947, 326; Austen, Stolthet og fordom, c. 1972, 301; Austen, Omvei til lykken, 1974, last instalment; Austen, Stolthet og fordom, 2003, 347. 
deserved by his [Sir Walter's] own", 4). Furthermore, there are other married couples serving as cases and illustrations, and not the least interesting are the relatively newly married young Musgroves as a counterpart to the mature couple, the Crofts. The ironic dismissal of the happiness of the first are discussed in Chapter 10 above (see page 164). The second is a remarkable example of a close and harmonious marriage, an Admiral whose wife follows him on voyages around the world instead of waiting and suffering at home, as she is expected to do. Their style of marriage is said to be similar to their style of driving: although he is at the reins, she quietly takes over when necessary to avoid them driving into things (end of $\mathrm{I}, 10$ ).

The 1871 translator makes no effort to avoid this view of an unorthodox marriage, and in fact renders it very well. Nevertheless, a later narrative comment implying that the Admiral is led by his wife is omitted: "as she [Anne] was not really Mrs Croft, she must let him have his own way". ${ }^{9}$ This is a tiny detail, however, and the highly pertinent discussion of whether a woman can be admitted aboard a Navy vessel is fully and well translated (I, 8). Mrs Croft here wins the day with her argument that women are not refined creatures that cannot brave the seas or discomforts, and that wives are happier joining their husbands on journeys than remaining at home. Furthermore, this is what the Crofts have practised for a long period, and they are demonstratively happy. Austen's happiest marriage is also a surprisingly equal one, conditions considered. This idyll is, however, more of an exception than a rule in her authorship. Most of the marriages in Pride and Prejudice, for instance, are less harmonious affairs, and only the Gardiners seem to have a similar relationship. ${ }^{10}$

\section{Irony on Lovers}

The happy ending of the novels is, then, set against the backdrop of mostly miserable marriages (the Gardiners and the Crofts excepted). Still, it is not only family embarrassments that lessen the heroine's happiness, it is the weaknesses of the lovers themselves. Even the condition of being in love is ironized by the author.

Austen's peculiarly ironic distance from young people falling in love is excellently translated in the 1871 Persuasion (I, 4). After listing their superior qualities, in the usual manner of love stories ("a remarkably fine young man", "an

$9 \quad$ Austen, Familien Elliot, 1871, 31 December 1871 and 11 January 1872.

10 For a fuller discussion of marriage in Austen's novels, see Sørbø, Irony and Idyll, 2014, Chapters 2 and 8. 
extremely pretty girl"), the author cannot refrain from displaying the ordinariness, and the utter naturalness of the entire process:

Half the sum of attraction, on either side, might have been enough, for he had nothing to do, and she had hardly any body to love; but the encounter of such lavish recommendations could not fail. They were gradually acquainted, and when acquainted, rapidly and deeply in love. $(26)^{11}$

This is fully rendered in Norwegian, complete with the somewhat irreverent refusal to romanticize the young lovers, and the unceremonious summary of their after all, very common, love story (see also page 100 above).

The translator has less success with the ironically tinged report of Anne's secret faithfulness to her love in the period he is lost to her:

Prettier musings of high-wrought love and eternal constancy, could never have passed along the streets of Bath, than Anne was sporting with from Camden Place to Westgate Buildings. It was almost enough to spread purification and perfume all the way. (192)

Jane Austen is not in the business of "high-wrought love" and "pretty musings", and makes fun even of her heroine's feelings when she loses contact with the ground. This distance is not captured in the Norwegian version when rendered:

Thus were Anne's thoughts and feelings, as she walked from Camden Place to Westgate Buildings. No woman has ever loved a man more warmly and faithfully, than she loved Frederick Wentworth. ${ }^{12}$

This time, Austen's irony about love and lovers is replaced by the standard repertoire of clichés of love stories. "No woman has ever loved ... more warmly ..." is exactly the kind of exaggeration Austen is mocking in this passage.

She does the same to her hero, Mr Darcy, in Pride and Prejudice. Instead of quoting fully his undoubtedly passionate words of love, when he finally gets

\footnotetext{
11 "Halvdelen av de tiltrækkende Egenskaber, begge besade, vilde været nok til at gjøre dem forelskede i hinanden; thi han havde Intet at tage sig til, og hun havde endnu aldrig seet Nogen, der kunde indgyde hende en varmere Følelse og det var saaledes ikke underlig, at begge snart blev saarede av Amors piler" (Austen, Familien Elliot, 22 December 1871).

12 "Saadanne var Anne's tanker og følelser, medens hun vandrede fra Camden Place til Westgate Buildings. Ingen Kvinde har nogensinde elsket en Mand varmere og trofastere, end hun elsket Frederick Wentworth" (ibid., last instalment, 1872).
} 
round to his second and successful proposal, the author gives us a teasing summary: "he expressed himself on the occasion as sensibly and as warmly as a man violently in love can be supposed to do" (366). The ironic distance is as palpable as the desired romance, as if readers cannot be allowed to see the latter without the filter of the first.

In the Hauges' $c .1972$ translation, the filter is removed, as "can be supposed to do" is no longer a modification, and "sensibly" is replaced by "sensitively". Their version is: "He expressed himself as warmly and as sensitively as only a man deeply in love can do". ${ }^{13}$ As is often the case, the new version seems deceptively like the original, but the basic tone is altered, and the effect is the opposite. Instead of smiling at the behaviour of people in love, we are led to believe in perfect love. Instead of a modification of love, we have a confirmation. Where Austen reminds us that men in love cannot expected to be entirely sensible, we are here told that they are models of warmth and sensitivity. Of the five translations, three present variants of such reinterpretations, while two have caught Austen's irony perfectly (in this instance the 1974 translator and Merete Alfsen). ${ }^{14}$

\section{Enhancing the Romance}

Particularly one of the Norwegian translators falls for the temptation to improve Jane Austen's love story by supplying more emotions than the author does. Lalli Knutsen adds to the meetings between Elizabeth and Darcy, and also Jane and Bingley's, and amplifies the romance. She makes Mr Darcy's early admiration of Elizabeth far more romantic in expression: he speaks to her with a "hushed, almost tender tone", while in English, it is simply "gallantry" (52). Furthermore, Knutsen amends Elizabeth's attitude to Darcy in one of their encounters at Netherfield by attaching the adjective "mildly" to her response, as well as making her "certain" rather than "suppose" that Darcy is without

13 "Han uttrykte seg så varmt og følsomt som bare en dypt forelsket mann kan gjøre" (Austen, Stolthet og fordom, c. 1972, 292).

14 "Han talte så varmt og forelsket som hun kunde vente" (Austen, Elisabeth og hennes søstre, 1930, 237); "Han strålte øyeblikkelig opp" (Austen, Stolthet og fordom, 1947, 316); "han uttrykte denne gleden og lykken på en så fornuftig måte som en kunne vente det av en forelsket person" (Austen, Omvei til lykken, 1974, last instalment); "han uttrykte seg i den anledning så forstandig og så varmt som man kan forvente av en mann som er lidenskapelig forelsket" (Austen, Stolthet og fordom, 2003, 337). 
weaknesses. ${ }^{15}$ Elizabeth is more correctly polite and less teasing, and her ironic outburst at the idea that Mr Darcy is not to be laughed at is here a mildly humorous observation. ${ }^{16}$

The 1947 translator seems to be strengthening Darcy's feelings and softening Elizabeth's resentment. This suspicion is confirmed when the attribute "the enigmatic" is prefixed to Darcy's name, contributing to the image of him as the dark and mysterious hero of sentimental romances. ${ }^{17}$ In keeping with this, Knutsen makes him even more distanced than he is in the original. "She thought how reserved and cold he had been the last time in the park" is an expansion and interpretation of "What a contrast did it offer to his last address in Rosing's Park" (252). ${ }^{18}$

Mr Darcy is also decidedly cooler towards Miss Bingley in Knutsen's perception of him. "But he was in no mood to talk to her" goes further than the original: "She could not win him, however, to any conversation" (55). "He barely answered once in a while" is colder and ruder than "he merely answered her question" (ibid.). ${ }^{19}$

In a similar amendment of characters' feelings, Bingley's care for Jane during their first meetings is also improved. In Knutsen's version, he moves the convalescing Jane around the room "a number of times" instead of once, before he becomes "completely lost to his surroundings", which is more romantically phrased than the author's cooler observation that he "talked scarcely to any one else" $(54) \cdot{ }^{20}$

The Hauge couple $(c .1972)$ are more inconsistent in sometimes seeming to reduce and at other times increase Darcy's feelings. His "restraint" (278) at Elizabeth's distress when Lydia elopes is translated as "coolness". Austen suggests that he struggles to keep his emotions under control, but the $c .1972$ translation suggests that he does not have them. His "tone of gentleness and commiseration" is simply "a mild tone". His "wretched suspense" is turned into a plain and prosaic statement: "Darcy was unhappy, but did not quite know

15 "den dempede, nesten ømme tonen"; "lunt”; "er jeg sikker på” (Austen, Stolthet og fordom, $1947,54,58)$.

16 The original reads: “Mr Darcy is not to be laughed at!' cried Elizabeth" (Austen, Pride and Prejudice, 1983, 57). The translation is: "Nei, herr Darcy er virkelig ikke et av de menneskene en ler av', sa Elizabeth lunt" (Austen, Stolthet og fordom, 1947, 58).

17 "den gåtefulle" (ibid., 83).

18 "Hun tenkte på hvor avmålt og kjølig han hadde vært den siste gangen i parken på Rosings, da han hadde gitt henne brevet" (ibid., 217).

19 "Men han var ikke i humør til å snakke med henne. Det var så vidt han svarte en gang imellom" (ibid., 56).

20 "diverse ganger"; "fullstendig tapt for omverdenen" (ibid., $5^{6}$ ). 
what he should say to comfort her". His outburst: "Would to Heaven that anything could be either said or done on my part that might offer consolation to such distress!" is clearly intensely felt in the original. It is much more diluted when he says instead: "I wish there was something I could say or do". ${ }^{21}$

However, the Hauges also, like Knutsen, add words to intensify Elizabeth's and Darcy's feelings. Darcy is said to "still have warm feelings towards her" after their first dance, where Austen says, "there was a tolerable powerful feeling towards her" (94). When Elizabeth is thinking of Pemberley, the Hauges specify "and those who lived there". Moreover, a direct declaration of love is added to Darcy's report of his growing interest in her. In English, he only refers to his dawning wishes to try to win her ("How soon any other wishes introduced themselves I can hardly tell, but I believe in about half an hour after I had seen you", 370). In Norwegian he says the same, but then continues, "I understood that I still cared for you".22 Enhancing love scenes and filling out missing or unsatisfactory expressions of feeling is part and parcel of some translators' strategies to improve on the author's love stories. There are further measures taken to achieve similar ends.

\section{Suppressing the Heroine's Other Loves}

One of Austen's modifications of the romance pattern is giving us a heroine that falls for other men, and seriously considers candidates other than the hero. Falling for the wrong man first, and then learning from her mistake, is, indeed, a common feature of romance, but the twist is that Elizabeth's feelings for these men are genuine, and she is not only superficial flirting. We get inside glimpses of her fascination, and her rational deliberations on what her future could be with them. It is not only the standard clichés of mistaken attraction, but a realistic description of the vicissitudes of love for any human being.

The two men she more or less falls in love with, or would if she could, are Mr Wickham and Colonel Fitzwilliam. Of the two, her feelings for Wickham are the earliest and deepest, and unmistakably pointed out by the narrator. Elizabeth is on the very brink of unhappiness when he discards her for a rich girl, but she disciplines herself to think better of it. With Colonel Fitzwilliam

\footnotetext{
21 "kjølighet”; "en mild tone”; “Darcy var ulykkelig, men visste ikke riktig hva han skulle si for å trøste henne"; "Jeg skulle ønske det var noe jeg kunne si eller gjøre” (Austen, Stolthet og fordom, c. 1972, 217-18). See also Chapter 11 above (pages 179-180).

22 "hadde fortsatt varme følelser for henne"; "og dem som bodde der"; "forsto jeg at jeg fortsatt var glad i deg" (ibid., 81, 209, 295).
} 
she has grown more cautious, but feels enough attraction to actively decide not to be made unhappy when she discovers that his aim is exactly the same as her first admirer - a rich wife.

Knutsen suppresses the fact that it is Elizabeth, before any of her sisters, who looks upon Wickham with admiration:

... when Mr Wickham walked into the room, Elizabeth felt that she had neither been seeing him before, nor thinking of him since, with the smallest degree of unreasonable admiration. ... Mr Wickham was ... far beyond them all in person, countenance, air, and walk .... (76)

Instead of Elizabeth's assessment and admiration of him, Knutsen transfers this passage to the other women: "he made an indelible impression on the young girls". The praise of his superiority is now instead the narrator's. ${ }^{23}$

Likewise, translators seem not to like Austen's wording and her focus on Elizabeth and Wickham's story, when she writes of their "happiness" that must be "delayed" since they cannot have the first dances together (87). Three translations omit the words. A fourth modifies them, so that Elizabeth's prospect of dancing with Mr Wickham is "happiness" in the original and only "fun" in the translation. There appears to be a wish to tone down the relationship. ${ }^{24}$

The only translator to keep these phrases, Alf Harbitz, is the one to reduce Elizabeth's later liking for Colonel Fitzwilliam. He cuts for instance half a paragraph where she compares the Colonel to Wickham, finding them both agreeable (180). ${ }^{25}$ The effect is reinforced by his deletion of Elizabeth's reflections on whether she will miss Colonel Fitzwilliam, and deciding not to do so ("agreeable as he was, she did not mean to be unhappy about him", 188). The translator, however, retains the information that Fitzwilliam no longer means anything to her four chapters later (209). ${ }^{26}$

In keeping with his reductions of Elizabeth's other flirtations, Harbitz likewise omits Mrs Gardiner's comparison of Darcy to Wickham at Pemberley: "he

\footnotetext{
23 "gjorde han et uutslettelig inntrykk på pikebarna" (Austen, Stolthet og fordom, 1947, 73).

24 Knutsen, the Hauges and the 1974 translator all delete these words. Alfsen translates them as "having fun": "Å more seg med mr. Wickham fikk hun gjøre etterpå" (Austen, Stolthet og fordom, 2003 87). Harbitz (1930) keeps these phrases intact.

25 Austen, Elisabeth og hennes søstre, 1930, 132. Knutsen has kept this (although simplified), but cut the last lines about Charlotte's plans for Elizabeth to marry Fitzwilliam (which Harbitz included). Alfsen and the Hauges have kept both passages, although the latter translation simplifies them. Alfsen is particularly successful in the first instance: "fikk henne til å minnes sin fordums yndling” (Austen, Stolthet og fordom, 2003, 173).

Austen, Elisabeth og hennes søstre, 1930, 136, 149.
} 
is not so handsome", and translates only her question about Darcy ("how came you to tell us that he was so disagreeable?", 257). It is as if our heroine should only seriously consider one man. Furthermore, the narrator's ironic reference to Elizabeth's "partiality for Wickham" and its slight success is lost along with the striking narrative comment on the nature of love (see Chapter 11 on Censorship, page 177 above) (279). ${ }^{27}$

\section{Austen's Doubleness and the Construction of the Simple Author}

Translators make modifications to Austen's love stories. This is hardly unexpected, partly because it has happened throughout the period of her reception, and partly because any translation is also an interpretation. It is, however, intriguing to observe what kinds of modifications are wanted, and consider what their purpose might be.

Amending the love stories by improving the impression of marriage, by enjoying love without ironic comments, by heightening the romantic pleasure, and by forgetting the complications of love among real people, are all strategies that are employed by many, sometimes most, of the Norwegian translators. Conversely, other translators have a keen eye on Austen's tone, and a convincing pen.

There is a doubleness to Jane Austen's own strategies. On the one hand, she provides the readers with engaging love stories, for which she has become increasingly popular in recent periods. On the other hand, she undermines the romance patterns she employs. ${ }^{28}$ The end of all her plots is marriage, yet happy marriages are thin on the ground in her books.

The key to the riddle is her bent for irony. She chose (if she had a choice) to write love stories with happy endings, but could not perform the task without an ironic, critical and humorous distance from the phenomenon of love and the practice of marriage. She claimed she could not have written a proper romance to save her life, ${ }^{29}$ the laughter would come in the way, as, indeed, it does throughout her novels.

27 Ibid., 172, 183.

28 For a consideration of Austen's anti-romantic features, see Sørbø 2014, $375 \mathrm{ff}$.

29 "I could not sit seriously down to write a serious Romance under any other motive than to save my Life, \& if it were indispensable for me to keep it up \& never relax into laughing at myself or other people, I am sure I should be hung before I had finished the first Chapter" (Deirdre Le Faye, Jane Austen's Letters, 1995, 312). 
Translations may serve to construct the desired image of an author through omissions and rewritings that transform and obscure the original. As André Lefevere shows in his study of the early translations of Anne Frank's diary, they tended to purge the original of anything consided indecorous, disrespectful of parents or neighbours, or even anti-German/fascist feelings. Intriguingly, also the young girl's drive to write, and her passages of complaint that "woman occupies a position so much lower than man's", were expunged from her text in the 195 os. $^{30}$ The image of the innocent young girl that fitted the decade's horizon of expectations was constructed.

Jane Austen's image is also sometimes reconstructed by translators, and she is reshaped as an unpretentious romance writer, an author of straightforward entertainment stories, with a more banal language style and more simple artistic aims. This is, indeed, the "Jane Austen" many non-readers seem to have in mind today as they refer to her adored "romances" as the best there are.

3o André Lefevere Translation, Rewriting and the Manipulation of Literary Fame, London and New York: Routledge, 2016 [1992], 59-72. 

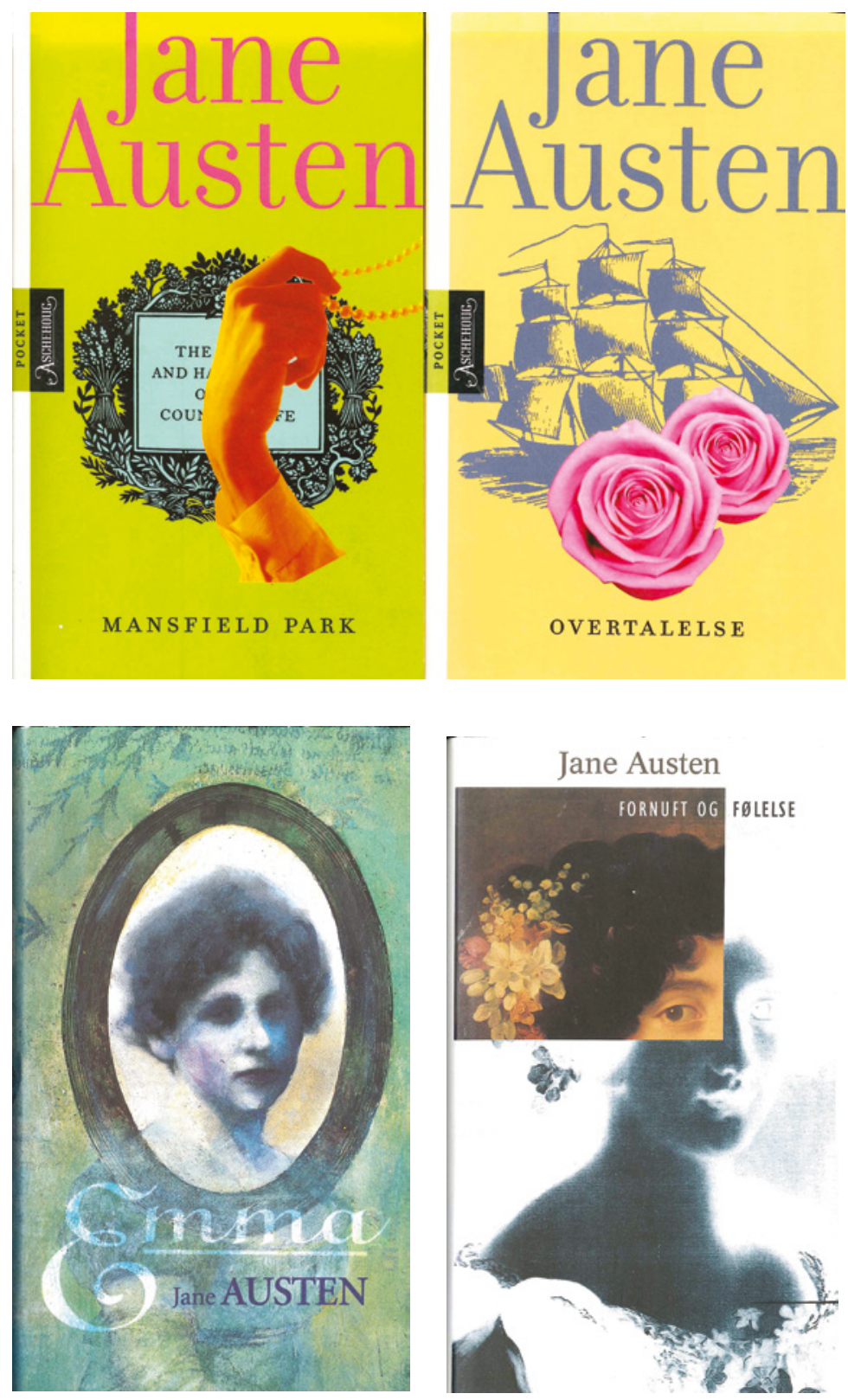

FIGURE 9 Five of Austen's novels were translated for the publisher Aschehoug between 1996 and 2003, and later reissued in for instance book-club and pocket editions (here from 1997, 2000 and 2006). 